\title{
Isotope fractionation between dissolved and suspended particulate Fe in the oxic and anoxic water column of the Baltic Sea
}

\author{
M. Staubwasser ${ }^{1}$, R. Schoenberg ${ }^{2}$, F. von Blanckenburg ${ }^{3}$, S. Krüger ${ }^{4}$, and C. Pohl ${ }^{4}$ \\ ${ }^{1}$ Institute of Geology and Mineralogy, University of Cologne, Greinstrasse 4-6, Building 902, 50939 Köln, Germany \\ ${ }^{2}$ Isotope Geochemistry, University of Tübingen, Wilhelmstrasse 56, 72074 Tübingen, Germany \\ ${ }^{3}$ German Research Centre for Geosciences - GFZ, Telegrafenberg, 14473 Potsdam, Germany \\ ${ }^{4}$ Leibniz-Institute of Baltic Sea Research, Seestr. 15, 18119 Warnemünde, Germany
}

Correspondence to: M. Staubwasser (m.staubwasser@uni-koeln.de)

Received: 14 March 2012 - Published in Biogeosciences Discuss.: 19 April 2012

Revised: 17 November 2012 - Accepted: 9 December 2012 - Published: 15 January 2013

\begin{abstract}
Fe}$ isotope ratios and concentrations of dissolved $\mathrm{Fe}\left(\mathrm{Fe}_{\mathrm{dis}},<0.45 \mu \mathrm{m}\right)$ and of suspended particulate $\mathrm{Fe}\left(\mathrm{Fe}_{\mathrm{SPM}}\right)$ were analyzed from a depth profile through the anoxic Eastern Gotland Basin water column, Baltic Sea. Results show a sharp gradient in $\delta^{56} \mathrm{Fe}_{\text {dis }}$ across the ferruginous layer with $\delta^{56} \mathrm{Fe}_{\text {dis }}=-0.4 \%$ in the euxinic deep basin and $\delta^{56} \mathrm{Fe}_{\text {dis }}=+0.3 \%$ in the oxic upper water column. The isotopic gradient overlaps with a strong concentration gradient of $\mathrm{Fe}_{\text {dis }}$, a concentration maximum in $\mathrm{Fe}_{\text {SPM }}$ and lower $\delta^{56} \mathrm{Fe}_{\mathrm{SPM}}$ values than $\delta^{56} \mathrm{Fe}_{\text {dis. }}$. These features indicate preferential loss of light $\mathrm{Fe}$ isotopes from solution to suspended iron-oxyhydroxides $\left(\mathrm{Fe}_{\mathrm{IOH}}\right)$ during typical oxidative precipitation across the redox interface. The sign of the overall fractionation, $\Delta^{56} \mathrm{Fe}_{\mathrm{Fe} \_\mathrm{IOH}}-\mathrm{Fe}(\mathrm{II})(\mathrm{aq})<0 \%$, is in contrast to similar, mostly non-marine redox environments, where $\Delta^{56} \mathrm{Fe}_{\mathrm{Fe} \_\mathrm{IOH}}-\mathrm{Fe}(\mathrm{II})(\mathrm{aq})>0 \%$. The difference appears to be the result of isotope exchange dominated by reaction kinetics in the marine water column, rather than equilibrium fractionation generally inferred for oxidative $\mathrm{Fe}$ precipitation elsewhere. High residual $\delta^{56} \mathrm{Fe}_{\text {dis }}$ immediately above the oxic-ferruginous interface and throughout the oxic water column suggests that any potential dissolved Fe export from marine reducing waters into the oxic open water column is enriched in the heavy isotopes. In the deep, mildly euxinic water column above the level of Fe sulfide saturation, a decreasing $\delta^{56} \mathrm{Fe}_{\mathrm{SPM}}$ trend with depth and a generally low $\delta^{56} \mathrm{Fe}_{\text {dis }}$ are comparable to trends generally observed in marine anoxic sediment profiles where microbial reductive Fe dissolution occurs. The isotope composition of the redoxcycled Fe inventory in anoxic marine basins mainly reflects
\end{abstract}

the balance between external fluxes, driving the composition towards crustal $\delta^{56} \mathrm{Fe}$ values, and intensity of internal recycling, driving $\delta^{56} \mathrm{Fe}$ towards negative values.

\section{Introduction}

The fractionation of $\mathrm{Fe}$ isotopes between coexisting dissolved and particulate $\mathrm{Fe}$ species within the environmental Fe redox cycle often imparts an isotopic signature on residual reaction components (Bullen et al., 2001; Anbar, 2004; Beard and Johnson, 2004). In principle, this may allow the identification of sources of $\mathrm{Fe}$ to the modern ocean by using the distinct isotopic signature of diagenetically redox-recycled $\mathrm{Fe}$ to discriminate against fluvial, dust and hydrothermal $\mathrm{Fe}$ (Severmann et al., 2006; Staubwasser et al., 2006; Anbar and Rouxel, 2007). A recent benthic flux chamber study demonstrates the efflux of low $\delta^{56} \mathrm{Fe}$ from early diagenetic recycling (Severmann et al., 2010). With only a few published values for seawater (Lacan et al., 2008; John et al., 2010, 2012; Gelting et al., 2010; Radic et al., 2011), but none from anoxic and euxinic marine basins, however, the database is currently very limited. Consequently, the general applicability of $\mathrm{Fe}$ isotopes as a direct tracer of diagenetic $\mathrm{Fe}$ redox cycling remains uncertain, and the controls of $\mathrm{Fe}$ isotope fractionation in the marine redox environment remain unverified. One exception is a study of the low oxygen San Pedro Basin at the Californian margin (John et al., 2012), where dissolved Fe isotope ratios in the water column appear to reflect 
a low $\delta^{56} \mathrm{Fe}$ diagenetic reflux from underlying ferruginous sediments.

Another application of marine $\mathrm{Fe}$ isotope fractionation lies in the understanding of the evolution of anoxic oceans and basins of the past by analyzing their sediments (Rouxel et al., 2005; Anbar and Rouxel 2007; Jenkyns et al., 2007; Johnson et al., 2008; Severmann et al., 2008; von Blanckenburg et al., 2008). Of particular interest is the observed occurrence of low $\delta^{56} \mathrm{Fe}$ in pyrites $\left(\delta^{56} \mathrm{Fe}\right.$ between -2 and $-4 \%$ ) and carbonates prior to the rise of atmospheric oxygen across the Archean-Proterozoic transition approximately $2.3 \mathrm{Ga}$ ago. These studies argue for the increasing role of microbially driven aqueous $\mathrm{Fe}$ redox cycling at the transition to an oxygenated surface ocean and atmosphere, fuelled by an increasing availability of reactive $\mathrm{Fe}$ oxides and leading to the accumulation of low $\delta^{56} \mathrm{Fe}$ in marine dissolved $\mathrm{Fe}$. The operation of a Proterozoic benthic iron shuttle - microbially derived dissolved $\mathrm{Fe}$ escaping from oxic shelf sediments, transported into the deep euxinic basin, precipitated and subsequently buried as sulfides - has been inferred from a moderate partition of low $\delta^{56} \mathrm{Fe}$ values $(>-1.5 \%$ ) into deep sea authigenic pyrites of modern anoxic basins with respect to average crustal $\delta^{56} \mathrm{Fe}$ values $(\sim 0.1 \%$ ) present in modern oxic shelf sediments (Severmann et al., 2008; Fehr et al., 2010). Water column processes involved in this concept, which was developed in the Black Sea (Wijsman et al., 2001; Anderson and Raiswell, 2004), however, have not yet been constrained directly by Fe isotope measurements of dissolved and suspended Fe. Data for Fe isotope fractionation during $\mathrm{Fe}$ cycling across water column redox boundaries are not yet available.

Modern anoxic basins, such as the central Baltic Sea, show intense redox cycling of $\mathrm{Fe}$ across the oxic-anoxic redox boundary in the water column. The cycle consists of reductive dissolution of $\mathrm{Fe}$ oxyhydroxides at anoxic conditions, upward turbulent diffusion, oxidative precipitation on contact with dissolved oxygen, and resettling of Fe oxyhydroxides back into the anoxic water column (Millero, 2006; Murray and Yakushev, 2006; Dellwig et al., 2010). Mn is recycled in a similar fashion, usually somewhat higher up in the water column but overlapping in parts with the Fe cycle. Removal from the Fe redox cycle occurs ultimately by settling of $\mathrm{Fe}_{\mathrm{IOH}}$ out of the water column and burial. If an euxinic layer is present due to sulfate reduction at greater depth, dissolved $\mathrm{Fe}$ concentration increases initially with depth (along with $\mathrm{H}_{2} \mathrm{~S}$ ) to a level where the solubility equilibrium of typical Fe-sulfides is reached, usually amorphous $\mathrm{FeS}$, pyrrhotite $(\mathrm{FeS})$ and greigite $\left(\mathrm{Fe}_{3} \mathrm{~S}_{4}\right)$ (Landing and Westerlund, 1988; Dyrssen and Kremling, 1990; Lewis and Landing, 1991). The ferruginous layer with reductive dissolution of Fe-oxyhydroxides is then condensed to the narrow zone between the redox interface and the euxinic layer. Below Fe-sulfide saturation depth, removal of $\mathrm{Fe}$ may occur as a result of $\mathrm{Fe}$-sulfide precipitation and burial. In addition, $\mathrm{Fe}$ oxyhydroxides may be transformed directly by sulfidization
(Dellwig et al., 2010). The high Fe inventory in the water column of anoxic basins is thought to be maintained by a combination of two sources. The first is diagenetic dissolved Fe from the shelf (Wijsman et al., 2001), which is oxidized in the water column and transported in a solid phase decoupled from lithogenous flux. The second is reductive dissolution of previously formed reactive Fe coupled to lithogenous flux (Anderson and Raiswell, 2004). Because the full range of modern marine redox conditions has been observed and monitored continuously over the course of many years, the Baltic Sea is well suited to study fundamental processes of redox related $\mathrm{Fe}$ isotope fractionation in the marine redox $\mathrm{Fe}$ cycle. The basin's redox zonation may also serve as a modern analogue to past anoxic oceans.

Several steps within the Fe-redox cycle described above may result in a fractionation of $\mathrm{Fe}$ isotopes between suspended and dissolved Fe. Reductive microbial dissolution of $\mathrm{Fe}_{\mathrm{IOH}}$ preferentially releases $\mathrm{Fe}$ with a low ${ }^{56} \mathrm{Fe}$ to ${ }^{54} \mathrm{Fe}$ ratio into solution (Crosby et al., 2007). If Fe-sulfides form in the euxinic water column, additional $\mathrm{Fe}$ isotope fractionation between dissolved and suspended particulate Fe may take place (Butler et al., 2005). Fe oxidation and precipitation in contact with oxygen in laboratory experiments as well as in continental and estuarine environments leads to a preferential sequestration of heavy isotopes into solid $\mathrm{Fe}_{\mathrm{IOH}}$ (Bullen et al., 2001; Beard and Johnson, 2004; Rouxel et al., 2008). Accordingly, any dissolved $\mathrm{Fe}$ remaining after oxidative Fe precipitation should have a lower ${ }^{56} \mathrm{Fe}$ to ${ }^{54} \mathrm{Fe}$ ratio than contemporary suspended Fe-oxyhydroxides. This oxidative precipitation is usually broken down into a two-step reaction with an equilibrium isotopic exchange between dissolved redox species and subsequent kinetic fractionation during precipitation (Anbar, 2004; Beard and Johnson, 2004). Very low ${ }^{56} \mathrm{Fe}$ to ${ }^{54} \mathrm{Fe}$ ratios should be observable in residual dissolved $\mathrm{Fe}$ after nearquantitative oxidative Fe-precipitation. Thus, dissolved $\mathrm{Fe}$ exported from marine oxic-anoxic redox boundaries could be isotopically distinguishable from Fe derived from other sources. However, the study presented here does not confirm this particular expectation. The Baltic Sea profile shows high ${ }^{56} \mathrm{Fe}$ to ${ }^{54} \mathrm{Fe}$ ratios in residual dissolved $\mathrm{Fe}$ above the oxic-anoxic redox boundary and indicates a more prominent role of kinetic isotope fractionation relative to equilibrium exchange in the marine environment.

\section{Baltic Sea hydrography, redox zonation, and state of Fe redox cycling in fall 2005}

The Eastern Gotland Basin (EGB) is the largest of a series of anoxic basins in the Baltic Sea with a maximum depth of $250 \mathrm{~m}$ (Fig. 1). Anoxic conditions in the Gotland Deep result from an estuarine-type circulation pattern in the Baltic Sea. This circulation results in stable stratification with a pronounced pycnocline due to strong gradients in temperature and salinity between approximately 60 and $90 \mathrm{~m}$ (Fig. 2a, 
b). Exchange of deep water with the adjacent North Sea is limited by a series of shallow sills (Meier et al., 2006; Matthäus et al., 2008). Water column ventilation by winter convection is confined to the upper $\sim 70 \mathrm{~m}$ (Fig. 2b). Smallvolume intrusions of warm but saline water in summer prevent complete oxygen consumption immediately below the pycnocline between approximately 90 and $125 \mathrm{~m}$ (Neretin et al., 2003; Matthäus et al., 2008; Turnewitsch and Pohl, 2010). Deeper water is only ventilated approximately once in a decade by major intrusions after storm-induced entrainment of salty water from the North Sea in winter. A downward succession of manganous, ferruginous, and sulfidic (euxinic) redox zones with somewhat overlapping boundaries is established below the pycnocline at $\sim 90 \mathrm{~m}$ a few years after deep water replacement events (Dellwig et al., 2010; Turnewitsch and Pohl, 2010; see Canfield and Thamdrup, 2009 , for terminology). During extended anoxic intervals redox boundaries shoal with progressing time and the ferruginous zone becomes somewhat compressed as the sulfidic boundary rises. All redox boundaries vary on a seasonal scale by approximately $10 \mathrm{~m}$ (Pohl et al., 2004). The last major intrusion prior to the study presented here occurred in winter 2003. Monthly monitoring of chemical properties in the EGB shows that, by the time of this study's sampling campaign in October 2005, anoxic conditions had returned below $125 \mathrm{~m}$ depth (Nausch et al., 2008). Euxinic conditions with moderate concentrations of total sulfide $\left(0-60 \mu \mathrm{M} \sum \mathrm{H}_{2} \mathrm{~S}\right)$ prevailed below $150 \mathrm{~m}$. During anoxic intervals, the EGB's redox zonation is principally similar to the upper $250 \mathrm{~m}$ of the Black Sea (Dellwig et al., 2010).

Vertical particle flux through the pycnocline in the EGB is strongly seasonal and dominated by biogenic organic matter in late summer and fall (Pohl et al., 2004). Vertical flux in winter is of lower magnitude and dominated by lithogenous aluminosilicates. Lithogenous particles originate from rivers and are distributed by turbulent transport in the water column above the pycnocline (Hille et al., 2006). While anthropogenic atmospheric flux affects some of the mobile trace elements of the EGB water column, this is not the case for Mn and Fe (Pohl et al., 2004; Pohl and Hennings, 2008). A distinction between atmospheric and fluvial lithogenous sources is not possible from water column measurements. Below the pycnocline a substantial flux of internally redoxcycled authigenic $\mathrm{MnO}_{\mathrm{x}}$ and $\mathrm{FeOOH}-\mathrm{PO}_{4}$ and relatively little lithogenous (detrital) flux is observed across the redox boundaries (Neretin et al., 2003; Dellwig et al., 2010). These minerals are formed by oxidative precipitation and result in suspended $\mathrm{Mn}\left(\mathrm{Mn}_{\mathrm{SPM}}\right)$ and $\mathrm{Fe}\left(\mathrm{Fe}_{\mathrm{SPM}}\right)$ maxima (Neretin et al., 2003; Pohl et al., 2004; Pohl and Hennings, 2008; Turnewitsch and Pohl, 2010). The high $\mathrm{Mn}_{\mathrm{SPM}}$ and FesPM zones may show as variable turbidity maxima in sensor profiles. The steep $\mathrm{Fe}$ concentration gradient generally found across the ferruginous zone - with Fe concentration reaching micromolar concentration - may sustain an eddy-diffusive upwards flux of dissolved Fe of up to $\sim 10-15 \mu \mathrm{mol} \mathrm{m}^{-2} \mathrm{~d}^{-1}$

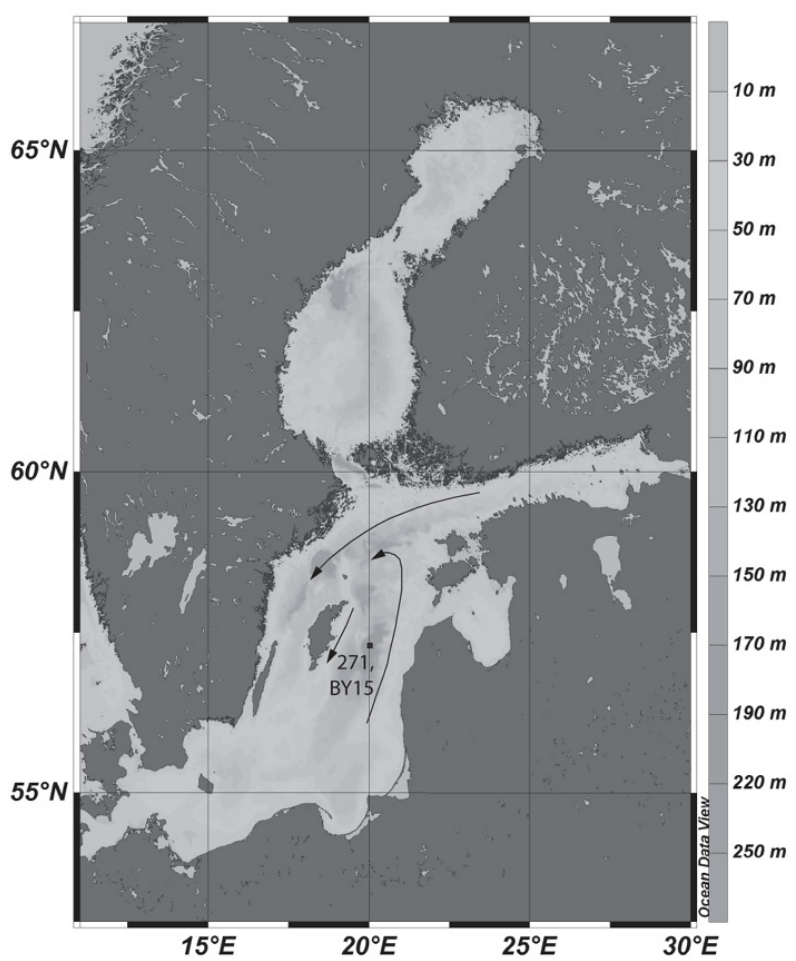

Fig. 1. Bathymetric map of the Baltic Sea with sampling station in the Eastern Gotland Basin and surface currents (Matthäus et al., 2008). Bottom currents are similar.

(Pohl and Hennings, 2005). In addition to vertical authigenic particle flux, there is considerable lateral lithogenous flux by near-bottom nepheloid transport, with a composition similar to the shallow basin margin surface sediments (Leipe et al., 2008). At the top of the sediment surface in the EGB, lateral nepheloid flux exceeds vertical flux. Unfortunately, the EGB near-bottom layer could not be sampled during the 2005 cruise.

The EGB water column in fall 2005 displays the typical Fe profile of a marine anoxic basin with intense Fe redox cycling across the ferruginous zone ( $\sim 120-170 \mathrm{~m}$, Fig. $2 \mathrm{c})$. Concentrations of dissolved $\mathrm{Fe}\left(\mathrm{Fe}_{\text {dis }}\right)$ of less than $10 \mathrm{nM}$ in the oxic surface layer increase to almost $400 \mathrm{nM}$ in the sulfidic water (as to the depth level sampled). At 120-140 m depth - the top of the ferruginous zone - oxidative precipitation results in a maximum concentration of suspended matter $\mathrm{Fe}\left(\mathrm{Fe}_{\mathrm{SPM}}\right)$, predominantly with iron oxyhydroxides $\left(\mathrm{Fe}_{\mathrm{IOH}}\right)$ comprising a mixed $\mathrm{MnO}_{\mathrm{x}}-\mathrm{FeOOH}-\mathrm{PO}_{4}$ phase at the top and FeOOH-PO ${ }_{4}$ inside the sulfidic zone (Dellwig et al., 2010). This $\mathrm{Fe}_{\text {SPM }}$ maximum broadly overlaps with a turbidity maximum sensor profile (Fig. 2b, c). The $\sim 10 \mathrm{~m}$ discrepancy in depth between $\mathrm{Fe}_{\text {SPM }}$ and turbidity is most likely due to the 2-day difference between Fe sampling and acquisition of the turbidity profile. Below the $\mathrm{Fe}_{\mathrm{SPM}}$ concentration maximum an increasing dissolution of $\mathrm{FeOOH}-\mathrm{PO}_{4}$ particles is visible in SEM/EDX imaging (Dellwig et al., 2010). 


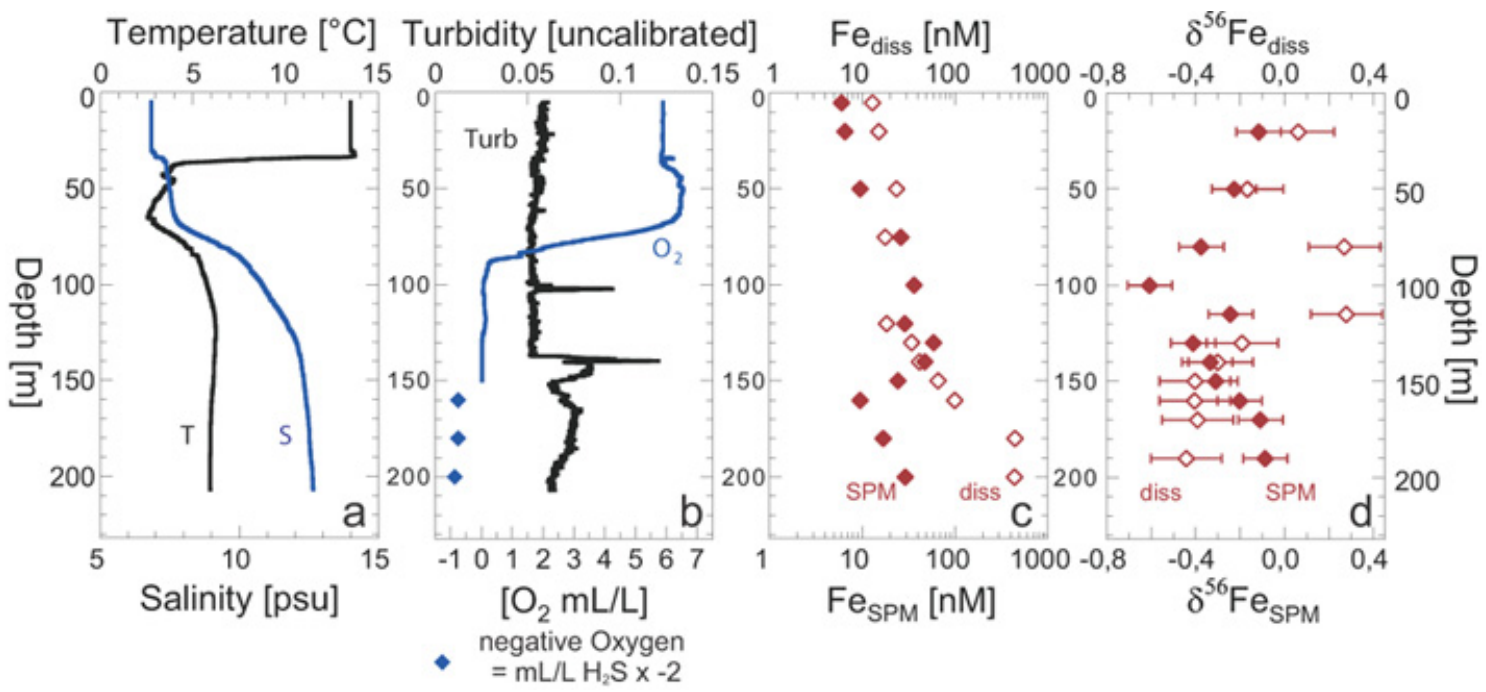

Fig. 2. Water column profile data for the Eastern Gotland Deep, central Baltic Sea, during October 2005: (a) temperature and salinity; (b) turbidity sensor data and dissolved oxygen concentration, with $\mathrm{H}_{2} \mathrm{~S}$ presented as negative oxygen (Grasshof et al., 1983); (c) concentration of soluble and suspended particulate $\mathrm{Fe}$; (d) Fe isotope ratios $\left(\delta^{56} \mathrm{Fe}\right)$ of soluble and suspended particulate $\mathrm{Fe}$, with error bars the respective external reproducibility calculated from replicates.

Regarding the euxinic layer (below $150 \mathrm{~m}$ ), a comparison of the fall 2005 profile data of $\mathrm{Fe}_{\mathrm{dis}}$ and $\sum \mathrm{H}_{2} \mathrm{~S}$ to the penultimate anoxic period studied in detail during 1981 and 1985 by Dyrssen and Kremling (1990) shows that both $\mathrm{Fe}_{\text {dis }}$ and $\sum \mathrm{H}_{2} \mathrm{~S}$ at $180 \mathrm{~m}$ are at the low end of concentrations generally sustained in the EGB euxinic waters. The 2005 values are well below the equilibrium concentrations of $\mathrm{FeS}$ determined for the fully developed euxinic EGB profiles in 1981 and 1985. Accordingly, no FeS was detected in the upper sulfidic water column by SEM scanning of suspended matter by Dellwig et al. (2010) in a study of the 2006 and 2007 water column at practically equal redox conditions relative to 2005 . FeS precipitation below $180 \mathrm{~m}$, however, or during later years with a fully developed euxinic layer, cannot be excluded entirely.

\section{Water column sampling and analytical methods}

\subsection{Water column sampling by pump-CTD and in-line filtration}

The site of sampling was monitoring station 271 at $57^{\circ} 18.3^{\prime} \mathrm{N}$ and $20^{\circ} 4.6^{\prime} \mathrm{E}$ in the Eastern Gotland Basin. All water samples were pumped by a trace metal suitable pumpCTD (P-CTD) system (Strady et al., 2008) fitted with a metal-free carbon fiber pump. The P-CTD allows salinity, temperature, pressure and $\mathrm{O}_{2}$ profiling, continuous water sampling from up to $400 \mathrm{~m}$ depth and subsequent inline filtration (see below) without exposure to atmosphere. To avoid memory effects from particles desorbing from the pump tube walls, the system was allowed 15 min of flush- ing time prior to sampling. To check against potential memory effects introduced by pumping particle-loaded seawater through more than $200 \mathrm{~m}$ of tubing, concentration measurements were also performed on a parallel bottle cast. Measured values were within agreeable limits with one notable exception from $100 \mathrm{~m}$ depth. This particular sample showed enrichment in soluble $\mathrm{Fe}$ concentration by a factor of two for the P-CTD and corresponding factor-two depletion in suspended Fe. This most likely indicates disintegration of particles during the pumping process. Accordingly, this sample was discarded from the list of isotope data (Table 1). Other non-trivial variability between bottle-casts and P-CTD measurements (e.g., $150 \mathrm{~m}$ ) was only observed within either the soluble or suspended fraction, respectively. These differences compare well with natural variability between parallel bottlecast profiles from previous studies. Such variability is most likely the result of water column inhomogeneity and internal waves that are readily observable during dissolved oxygen and turbidity monitoring over the course of a few hours. All data are summarized in Table 1.

Samples for trace metal concentration and for Fe isotope analysis were taken from parallel profiles. Samples for concentration measurements were processed according to established monitoring procedures (Pohl et al., 2004). For Fe isotope analysis, two liters were filtered in-line directly from the P-CTD through acid-clean $0.45 \mu$ PTFE filters (Millipore hydrophilic PTFE) in a PFA housing (Savillex). High particle loads required a change of filter after each liter of seawater filtered. Samples were acidified with double distilled $\mathrm{HNO}_{3}$ to $\mathrm{pH} \approx 2$ and stored until processing and analysis on shore. All handling of samples and filters on board was performed inside an ISO 5 (class-100) laminar flow hood. 
Table 1. $\delta^{56} \mathrm{Fe}$ of $\mathrm{Fe}_{\mathrm{dis}}$ and $\mathrm{Fe}_{\mathrm{SPM}}$ in the Eastern Gotland Basin.

\begin{tabular}{|c|c|c|c|c|c|c|c|c|c|}
\hline & & & Fe dissolved & Fe dissolved & Fe dissolved & & Fe SPM & Fe SPM & Fe SPM \\
\hline Depth (m) & Notes & Sal & $\mathrm{O}_{2}\left(\mathrm{mLL}^{-1}\right)$ & $\mathrm{Fe}(\mathrm{nM})$ & $\delta^{56} \mathrm{Fe}$ & $\pm 2 \mathrm{se}^{3}$ & $\mathrm{Fe}(\mathrm{nM})$ & $\delta^{56} \mathrm{Fe}$ & $\pm 2 \mathrm{sd}^{3}$ \\
\hline 5 & & 6.82 & 6.87 & 13.0 & & & 6.1 & & \\
\hline \multirow[t]{3}{*}{20} & average & 6.83 & 6.87 & 15.3 & 0.06 & 0.11 & 6.6 & -0.12 & 0.08 \\
\hline & replicate & & & & 0.19 & 0.11 & & & \\
\hline & replicate & & & & -0.06 & 0.11 & & & \\
\hline 50 & & 7.47 & 7.49 & 23.8 & -0.17 & 0.12 & 9.6 & -0.23 & 0.08 \\
\hline 75 & & 8.53 & 4.26 & 18.0 & & & 26.5 & & \\
\hline 80 & & & & & 0.27 & 0.09 & & -0.37 & 0.09 \\
\hline 100 & & 10.79 & 0.12 & 36.4 & $(0.55)^{2}$ & $(0.09)^{2}$ & 36.9 & -0.61 & 0.09 \\
\hline 115 & & 11.43 & 0.11 & & 0.28 & 0.11 & & -0.24 & 0.09 \\
\hline 120 & & 11.73 & 0.09 & 18.6 & & & 29.0 & & \\
\hline 130 & & 11.96 & 0.05 & 34.6 & -0.19 & 0.08 & 59.3 & -0.41 & 0.09 \\
\hline 140 & & 12.18 & 0.03 & 41.9 & -0.30 & 0.09 & 48.1 & -0.33 & 0.09 \\
\hline \multirow[t]{3}{*}{150} & average & 12.29 & 0.07 & 66.3 & -0.40 & 0.09 & 24.4 & -0.31 & 0.09 \\
\hline & replicate & & & & -0.43 & 0.08 & & & \\
\hline & replicate & & & & -0.38 & 0.09 & & & \\
\hline \multirow[t]{3}{*}{160} & average & 12.37 & $-0.75^{1}$ & 101.1 & -0.40 & 0.09 & 9.6 & -0.20 & 0.09 \\
\hline & replicate & & & & -0.36 & 0.10 & & & \\
\hline & replicate & & & & -0.45 & 0.09 & & & \\
\hline \multirow[t]{3}{*}{170} & average & & & & -0.39 & 0.09 & & -0.11 & 0.09 \\
\hline & replicate & & & & -0.46 & 0.08 & & & \\
\hline & replicate & & & & -0.33 & 0.09 & & & \\
\hline 180 & & 12.50 & $-0.75^{1}$ & 448.0 & & & 17.1 & & \\
\hline 190 & average & & & & -0.44 & 0.08 & & -0.09 & 0.08 \\
\hline & replicate & & & & -0.37 & 0.08 & & & \\
\hline & replicate & & & & -0.52 & 0.08 & & & \\
\hline 200 & & 12.60 & $-0.87^{1}$ & 445.4 & & & 29.5 & & \\
\hline
\end{tabular}

${ }^{1} \mathrm{H}_{2} \mathrm{~S}$ as negative oxygen $\left(=\mathrm{mLL}^{-1} \mathrm{H}_{2} \mathrm{~S} \times-2\right.$, Grasshoff et al., 1983); ${ }^{2}$ discarded (see text); ${ }^{3}$ internal precision $(2 \mathrm{se})$, external reproducibility (2 sd) given in the text.

\subsection{Concentration and isotope analysis}

Samples for $\mathrm{Fe}$ concentration were analyzed by AAS (Atomic Absorption Spectrometry) after a high pressure $\mathrm{HF}-\mathrm{HNO}_{3}-\mathrm{HCl}$ assay and liquid-liquid extraction for suspended and dissolved Fe, respectively (Pohl et al., 2004). For the isotope analysis of soluble $\mathrm{Fe}$, a ${ }^{54} \mathrm{Fe}-{ }^{58} \mathrm{Fe}$ double spike approach was used. The spike was calibrated against IRMM-14 standard and an in-house Fe solution (JM puratronic, $\delta^{56} \mathrm{FeIRMM}=0.42$ ). The $\delta^{56} \mathrm{FeIRMM}$ values (in short, $\delta^{56} \mathrm{Fe}$ ) are defined as

$\delta^{56} \mathrm{Fe}=\frac{\left({ }^{54} \mathrm{Fe} /{ }^{56} \mathrm{Fe}\right)_{\text {sample }}}{\left({ }^{54} \mathrm{Fe} /{ }^{56} \mathrm{Fe}\right)_{\text {IRMM-14 }}}-1$.

The double spike was added to sample aliquots ranging from $20-1000 \mathrm{~mL}$ (according to Fe concentration) and allowed $24 \mathrm{~h}$ of equilibration time. An experimental study on $\mathrm{Fe}$ isotope equilibrium exchange between inorganic and siderophore-complexed Fe (Dideriksen et al., 2008) confirms complete spike-sample equilibration within this time. Fe was co-precipitated with $\mathrm{Mg}(\mathrm{OH})_{2}$ twice by addition of ammonia (Wu, 2007). The precipitation may not be entirely quan- titative at the presence of strong Fe-binding organic ligands (Dideriksen et al., 2008), but the double spike calculation procedure corrects internally for any potential massdependent fractionation due to loss during separation chemistry as well as instrumental fractionation due to any potential residual matrix present in the analysis solution and the substantial mass bias introduced by the mass spectrometer's interface (Schoenberg et al., 2008). After ion exchange separation (Schoenberg and von Blanckenburg, 2005), measurements were made on 200-400 ng Fe with a Thermo Finnigan Neptune MC-ICP-MS and an ESI Apex-Q desolvator. Mass bias was corrected internally and monitored by bracketing standards. Possible interference by ${ }^{54} \mathrm{Cr}$ and ${ }^{58} \mathrm{Ni}$ was monitored through ${ }^{52} \mathrm{Cr}$ and ${ }^{60} \mathrm{Ni}$. Combinations of $\mathrm{H}, \mathrm{C}, \mathrm{N}$ and $\mathrm{O}$ from residual organic components and of the same elements with Ar that may add up to interfere with the four $\mathrm{Fe}$ isotopes are resolved by measuring in the instrument's medium resolution mode, which has a mass resolution of $\Delta \mathrm{m}^{-1} \approx 8000$ (10\% valley). Particulate Fe was leached from the PTFE filters with aqua regia at $120^{\circ} \mathrm{C}$, purified by ion exchange and measured by standard bracketing. 
External reproducibility $(\sigma \sigma)$ for dissolved Fe and doublespike measurements as calculated from the mean square of all replicate sample variances is $0.16 \%$ (Miller and Miller, 2005; replicates as given in Table 1). External analytical uncertainty $(\sigma \sigma)$ of leached particulate Fe and standard bracketing measurements is $\sim 0.10 \%$ o (Staubwasser et al., 2006). Total blanks were measured by isotope dilution and did not exceed $20 \mathrm{ng}$ for the separation procedure from seawater and $15 \mathrm{ng}$ for the filter samples. Low sample concentration and somewhat higher blanks in dissolved samples - probably due the more extensive separation procedure - may be the reason for the larger uncertainty in the dissolved Fe samples.

\section{Results and discussion}

Both the dissolved and suspended matter profiles show systematic isotope trends with depth (Fig. 2d). The $\delta^{56} \mathrm{Fe}_{\text {dis }}$ in the oxic layer is persistently higher than in the anoxic layer with a sharp transition at the redox transition. The profile of $\delta^{56} \mathrm{Fe}_{\mathrm{SPM}}$ shows the lowest values in the depth interval from the ferruginous layer to the top of the halocline at $\sim 70 \mathrm{~m}$, but includes some scatter at 130 and $100 \mathrm{~m}$, i.e., within and immediately above the ferruginous layer. In the following, the profiles will be discussed in terms of chemical reactions and transport paths along the typical internal marine Fe redox cycle of anoxic basins (Millero, 2006) in turn for the ferruginous layer, the (mildly) euxinic layer at greater depth, and the oxic surface layer.

\subsection{Fe isotope fractionation across the ferruginous layer}

\subsubsection{The relationship between $\delta^{56} \mathrm{Fe}_{\text {dis }}$ and $\delta^{56} \mathrm{Fe}$ SPM}

Below the ferruginous layer at depths greater than $150 \mathrm{~m}$, values of $\delta^{56} \mathrm{Fe}_{\text {dis }}$ are fairly constant at $\sim-0.4 \%$. Between $150 \mathrm{~m}$ and $115 \mathrm{~m}$ depth - across the ferruginous zone and its upper boundary $-\delta^{56} \mathrm{Fe}_{\text {dis }}$ values increase from $-0.4 \%$ o to $+0.3 \%$ along with a corresponding decrease of dissolved Fe concentration and a maximum in both turbidity and suspended Fe (Fig. 2b, c, d). A marked change in the difference between corresponding $\delta^{56} \mathrm{Fe}_{\mathrm{SPM}}$ and $\delta^{56} \mathrm{Fe}_{\text {dis }}$ values occurs at the base of the ferruginous layer. Below it, in the euxinic layer, $\delta^{56} \mathrm{Fe}_{\mathrm{SPM}}\left(0.1 \%\right.$ ) is higher than $\delta^{56} \mathrm{Fe}_{\text {dis }}(-0.4 \%$ ). Inside the ferruginous layer and above it, $\delta^{56} \mathrm{Fe}_{\mathrm{SPM}}$ is $-0.4 \%$ o on average and significantly lower than $\delta^{56} \mathrm{Fe}_{\text {dis }}(0.3 \%$ ), particularly at the top of the layer.

Concentration profiles of $\mathrm{Fe}_{\text {dis }}$ and $\mathrm{Fe}_{\mathrm{SPM}}$ in the EGB during this and previous cruises (Pohl et al., 2004; Pohl and Hennings, 2005, 2008) are similar to anoxic basin profiles in general (Millero, 2006) and are typically viewed as the result of upwards turbulent diffusion and oxidation of reduced $\mathrm{Fe}_{\text {dis }}$, removal by precipitation and subsequent settling across the ferruginous layer. The authigenic formation of $\mathrm{Fe}$ oxyhydroxides has been demonstrated directly (Dellwig et al., 2010). It is therefore reasonable to begin the discussion of isotope values in light of this established redox sequence.

On oxidation of dissolved ferrous Fe, precipitation probably results in the formation of $\mathrm{Fe}_{\mathrm{IOH}}$ particles in the colloidal size spectrum initially, but the maximum in Fe $\mathrm{SPM}_{\mathrm{SP}}$ concentration within the ferruginous layer indicates rapid coagulation and ultimate removal from $\mathrm{Fe}_{\text {dis. }}$. The corresponding isotopic trend upwards across the ferruginous layer suggests that the loss of $\mathrm{Fe}_{\text {dis }}$ due to oxidation/precipitation is accompanied by preferential loss of light Fe isotopes. This causes $\delta^{56} \mathrm{Fe}_{\mathrm{SPM}}$ to become lower than the corresponding residual $\delta^{56} \mathrm{Fe}_{\text {dis }}$. We note that this preferential low $\delta^{56} \mathrm{Fe}$ removal from solution into an oxidized solid phase is seemingly at odds with previous observations, except for another recently published profile from the oxygen-depleted San Pedro Basin on the Californian margin (John et al., 2012). This aspect will be discussed in the next chapter.

Ideally, in a closed system with in-situ $\mathrm{Fe}_{\mathrm{IOH}}$ precipitation, mass balance requires that the trend in $\delta^{56} \mathrm{Fe}_{\mathrm{SPM}}$ follow $\delta^{56} \mathrm{Fe}_{\text {dis }}$ with an offset. This may indeed be the case for the two samples inside the $\mathrm{Fe}_{\text {dis }}$ concentration gradient at the top of the ferruginous layer ( $130 \mathrm{~m}$ and $115 \mathrm{~m}$ ), but sample resolution is too low for a definite conclusion. A clear trend in $\delta^{56} \mathrm{Fe}_{\mathrm{SPM}}$ would not necessarily have to be expected for a number of reasons. Because the redox boundary shoals and deepens seasonally by about $10 \mathrm{~m}$ (Pohl et al., 2004), different generations of precipitated particles from different horizons in the redox sequence may mix to some degree with actually precipitating particles. In addition, preformed particles, such as lithogenous reactive $\mathrm{Fe}_{\mathrm{IOH}}$ and Fe-bearing silicates - either settling from above or transported laterally most likely would contribute to the total pool of $\mathrm{Fe}_{\text {SPM }}$ and obscure any trend related to authigenic precipitation. However, a minor role of silicates within the suite of preformed particles inside the turbidity maximum can be inferred from two independent observations. One is a dominance of authigenic Mn-oxide and Fe-oxyhydroxide particles across the manganous and ferruginous layers observed by Dellwig et al. (2010) in a 2006 cruise. The other is a lack of change in trace elements associated with Fe-bearing silicates. Ni readily substitutes for Fe in silicates (Krauskopf and Bird, 1995). Cluster analysis shows that $\mathrm{Ni}$ is associated with $\mathrm{Fe}$ and $\mathrm{Al}$ particularly during times of high lithogenous flux in winter (Pohl et al., 2004). A profile from winter 2006 - collected only three months after this study's profile - demonstrates the absence of any suspended Ni maxima in the profile, particularly across the broad $\mathrm{Fe}_{\mathrm{SPM}}$ maximum (Fig. 3). This confirms that the Fe-rich particle maximum is the consequence of precipitation in-situ rather than particulate Fe resuspended from silicate-rich sediments along the basin's margin. 


\subsubsection{Kinetic control of isotope fractionation during oxidative Fe precipitation at the top of the ferruginous layer}

Low $\delta^{56} \mathrm{Fe}$ removal across the redox boundary in the EGB on oxidative precipitation is the opposite of what has been found in previously studied natural and experimental redox environments. The natural environments studied include continental streams and groundwaters, anoxic lakes and estuarine groundwater discharge plumes, but not marine anoxic basins (Bullen et al., 2001; Anbar, 2004; Beard and Johnson, 2004; Busigny et al., 2008; Rouxel et al., 2008; Teutsch et al., 2009). The observed enrichment of heavy Fe isotopes in the solid fractionation during oxidative precipitation matches controlled $\mathrm{Fe}$ oxidation and precipitation - both in inorganic and microbial experiments - with $\mathrm{Fe}$ concentrations in the high micromolar range and $\mathrm{pH}<7$ (Skulan et al., 2002; Welch et al., 2003; Beard and Johnson, 2004; Croal et al., 2004).

The overall isotope reaction of the above studies has been explained with a simplified two-step reaction model, $\mathrm{Fe}(\mathrm{II})_{\mathrm{aq}} \leftrightarrow \mathrm{Fe}(\mathrm{III})_{\mathrm{aq}} \rightarrow \mathrm{Fe}_{\mathrm{IOH}}$ and an overall effective fractionation factor, $\Delta^{56} \mathrm{Fe}_{\mathrm{IOH}-\mathrm{Fe}(\mathrm{II})}$ (Anbar, 2004; Beard and Johnson, 2004). Beard and Johnson (2004) highlight the dependence of effective $\Delta^{56} \mathrm{Fe}_{\mathrm{IOH}-\mathrm{Fe}(\mathrm{II}) \mathrm{aq}}$ on the relative magnitude of reaction rate constants of the two sequential reaction steps, $\mathrm{Fe}^{2+}(\mathrm{aq}) \leftrightarrow \mathrm{Fe}^{3+}(\mathrm{aq}) \rightarrow \mathrm{Fe}_{\mathrm{IOH}}$, where rate constant $k_{1}$ determines the (pseudo-first order) removal reaction of $\mathrm{Fe}^{2+}(\mathrm{aq})$ by oxidation and $k_{2}$ the removal rate of $\mathrm{Fe}^{3+}(\mathrm{aq})$ by $\mathrm{Fe}_{\mathrm{IOH}}$ precipitation, respectively. The effective fractionation factor $\Delta^{56} \mathrm{Fe}_{\mathrm{IOH}-\mathrm{Fe}(\mathrm{II}) \mathrm{aq}}=0.9 \%$ of the overall reaction observed in laboratory experiments simulating oxidative precipitation in a natural continental stream environment (Bullen et al., 2001) was reproduced in a model calculation (henceforth BJ04) for a ratio of reaction rate constants $k_{2} / k_{1}=5$ (Beard and Johnson, 2004). Under such conditions, isotopic equilibrium is thought to be achieved rapidly between dissolved redox species - at a much faster rate than the removal of $\mathrm{Fe}^{2+}(\mathrm{aq})$. The isotopic equilibrium reaction results in a $\sim 3 \%$ enrichment of the heavier isotope in the $\delta^{56} \mathrm{Fe}$ of $\mathrm{Fe}$ (III) (Welch et al., 2003). This is followed by a kinetic $1-2 \%$ o depletion of $\mathrm{Fe}_{\mathrm{IOH}}$ in the heavier isotope on precipitation (Skulan et al., 2002). In general, the two-step isotope overall reaction in the above environments is thought to be dominated by isotopic equilibrium exchange that comes with an effective overall fractionation factor $\Delta^{56} \mathrm{Fe}_{\mathrm{IOH}-\mathrm{Fe}(\mathrm{II})}>0 \%$ or $\alpha^{56} \mathrm{Fe}_{\mathrm{IOH}-\mathrm{Fe}(\mathrm{II})}>1$, respectively.

The light-isotope enrichment of the oxidized solid Fephase at the redox interface within the marine EGB, however, suggests an effective $\Delta^{56} \mathrm{Fe}_{\mathrm{IOH}-\mathrm{Fe}(\mathrm{II}) \mathrm{aq}}<0 \%$, rather than $>0 \%$, or effective $\alpha^{56} \mathrm{Fe}_{\mathrm{IOH}-\mathrm{Fe}(\mathrm{II}) \mathrm{aq}}<1$ rather than $>1$, respectively. We can apply the BJ04 model - with the same fractionation factors for both reaction steps and the same ratio of $k_{2} / k_{1}$ as above - to calculate an expected isotopic com- position of residual $\mathrm{Fe}_{\text {dis }}$ above the ferruginous layer of the EGB. After $95 \% \mathrm{Fe}_{\text {dis }}$ removal from the typical concentration at the base of the layer, where initial $\delta^{56} \mathrm{Fe}_{\text {dis }}=-0.4 \%$, the value for $\delta^{56} \mathrm{Fe}_{\mathrm{dis}}=-2.7 \%$ at the top of the layer. The measured value above the EGB oxic-ferruginous interface is very different from that $\left(\delta^{56} \mathrm{Fe}_{\mathrm{dis}}=+0.3 \%\right.$ ) . Consequently, rapid equilibration during the first step in the overall reaction scheme of $\mathrm{Fe}(\mathrm{II})_{\mathrm{aq}} \leftrightarrow \mathrm{Fe}(\mathrm{III})_{\mathrm{aq}} \rightarrow \mathrm{Fe}_{\mathrm{IOH}}$ cannot explain observations in the EGB. The observed trend in the EGB towards $\delta^{56} \mathrm{Fe}_{\mathrm{dis}}=+0.3 \%$ may be achieved, however, using BJ04 with a ratio of $k_{2} / k_{1} \sim 0.7$. This result suggests that the change of sign in the effective overall fractionation factor may be the consequence of a higher removal (or oxidation) rate constant of $\mathrm{Fe}(\mathrm{II})_{\mathrm{aq}}$ in the marine environment in comparison to a continental stream environment.

As isotopic equilibrium is not a likely condition, this leads to the deduction that kinetic effects may dominate the effective fractionation factor in the marine environment. Two lines of argument principally support this conclusion. The first follows Anbar (2004), who discussed equilibrium and kinetic end-members of the isotopic exchange during the two-step oxidative precipitation of $\mathrm{Fe}$ in terms of kinetic isotope reaction theory: a kinetic dominance of the effective overall fractionation factor results, if the precipitation rate constant $\left(k_{2}\right)$ is much larger than the one for the back-reduction of $\mathrm{Fe}(\mathrm{IIII})_{\mathrm{aq}}$ $\left(k_{-1}\right.$, in contrast to the forward oxidation rate constant $\left.k_{1}\right)$. This can, for example, be achieved by changing the reaction type as a consequence of different $\mathrm{Fe}$-species involved each with a different rate constant - or having parallel reactions with different rate constants that contribute to the overall reaction at variable proportions in response to changes in environmental conditions. The other line of argument - suggested by John et al. (2012) - would change the reaction rates of the two successive steps in the overall reaction as a result of the comparably low concentrations of $\mathrm{Fe}_{\text {dis }}$ observed in the marine environment. In the most extreme case, a sufficient slow-down of the precipitation could allow oxidation running to completion before significant amounts of $\mathrm{Fe}_{\mathrm{IOH}}$ precipitate. This would result in an overall isotope fractionation factor that is entirely controlled by (kinetic) precipitation. The following section discusses potential reaction paths and environmental constraints for these two principal types of kinetically dominated $\mathrm{Fe}$ isotope fractionation during oxidative precipitation.

\subsubsection{Reaction paths}

Plausible reaction paths for the first of the two kinetic options discussed above can be attained from a suite of published experimental studies. Pham and Waite (2008) conducted experiments of marine oxidative Fe precipitation and modeled rate constants for inorganic reaction paths for $\mathrm{Fe}$ oxidation and precipitation. $\mathrm{Fe}_{\mathrm{dis}}$ concentration in the experiments was comparable to EGB observations. Other relevant environmental parameters taken from EGB monitoring 


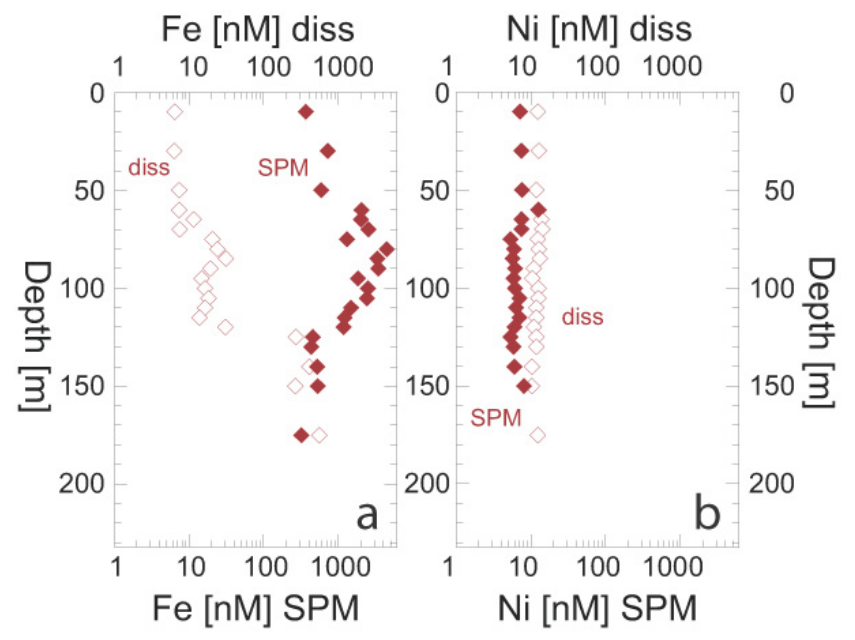

Fig. 3. Profiles of (a) Fe and (b) Ni for the Eastern Gotland Basin. Samples were collected early in January 2006, three months after the profiles shown in Fig. 2 and processed in the same way (see Sect. 3.2).

data (Karlson et al., 2009) show $\mathrm{pH}>7$ (Fig. 4) and that high alkalinity prevailed in the ferruginous layer, similar to the Pham and Waite (2008) experiments. Under such conditions, oxidation rate constants $\left(k_{1}\right.$ in the terms of the previous chapter) increase with $\mathrm{pH}$ due to an increasing involvement of rapidly oxidizing Fe-carbonate species, and a low back-reduction rate constant $\left(k_{-1}\right)$ due to competition with rapid precipitation $\left(k_{2}\right)$. Another important type of reaction is apparent from the suspended matter study by Dellwig et al. (2010), who suggest rapid oxidation of $\mathrm{Fe}^{2+}$ in the presence of Mn-oxides.

The other option for kinetic isotope fractionation dominance may in principle be achieved by decoupling the oxidation from precipitation, as suggested by John et al. (2012). Oxidation would quickly run to completion, followed by a slow precipitation out of a pool of stabilized Fe(III) dis. Stabilization of $\mathrm{Fe}(\mathrm{III})_{\text {dis }}$ could be achieved by organic ligands. In principle, quantitative oxidation followed by sluggish precipitation from an organic ligand-bound pool of dissolved $\mathrm{Fe}$ (III) could be an alternative reaction path considering Feisotope fractionation factors alone (Dideriksen et al., 2008).

A definite conclusion as to which one of the two options is more plausible is not possible at this point. Oxidative $\mathrm{Fe}$ precipitation in the San Pedro Basin (John et al., 2012) and the EGB (this study) appear to be controlled by reaction kinetics, but multiple reaction paths are possible. For comparison, the $\mathrm{Fe}_{\text {dis }}$ concentration gradient associated with $\delta^{56} \mathrm{Fe}$ change in the San Pedro Basin is $\sim 160 \mathrm{~m}$ thick and situated well outside the ferruginous layer (John et al., 2012). In the $\mathrm{EGB}$, the $\mathrm{Fe}_{\text {dis }}$ concentration gradient associated with $\delta^{56} \mathrm{Fe}$ change is $\sim 30 \mathrm{~m}$ and overlaps with the ferruginous layer. In addition, $\mathrm{Fe}_{\text {dis }}$ concentration - and presumably $\mathrm{Fe}_{\mathrm{SPM}}$ as well - are 1-2 orders of magnitude higher in the EGB com-

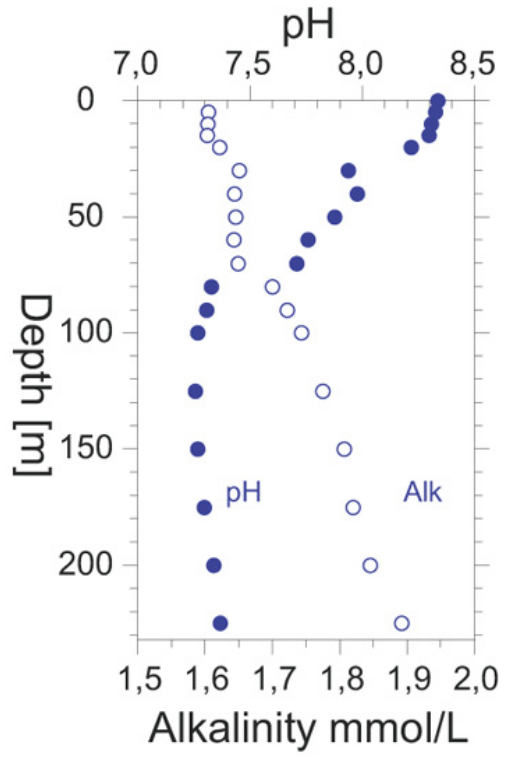

Fig. 4. Profiles of $\mathrm{pH}$ and alkalinity in fall 2005 for the Eastern Gotland Basin. Data are from the Swedish Meteorological and Hydrological Institute's monitoring program (Karlson et al., 2009), station BY-15 (which is identical to station 271 of this study).

pared to the Californian margin basins. To explain observations from the EGB, we lean towards the first option, i.e., different rate constants due to different types of reaction involved, because of the observed active involvement of suspended $\mathrm{Mn}$ particles in the oxidative precipitation of $\mathrm{Fe}_{\mathrm{dis}}$ (Dellwig et al., 2010). The replacement of $\mathrm{Mn}$ by Fe in the suspended authigenic mineral phases near the top of the ferruginous layer would be difficult to explain without a redox reaction taking place. Also, the presence of particulate authigenic $\mathrm{Fe}_{\mathrm{IOH}}$ (Fe-oxyhydroxides with phosphate, Dellwig et al., 2010) throughout the ferruginous layer would lend support to a reaction path controlled by $\mathrm{Fe}_{\mathrm{IOH}}$ particles present and $\mathrm{pH}$, as proposed by Pham and Waite (2008).

It is noteworthy that the observation of initially light $\mathrm{Fe}_{\text {SPM }}$ becoming isotopically heavier on progressive oxidative precipitation in a buoyant hydrothermal plume of a basaltic vent system in the Atlantic (Bennett et al., 2009) is essentially similar to the observation made in the EGB. This may suggest a general kinetic nature of $\mathrm{Fe}$ isotope fractionation during oxidative precipitation of $\mathrm{Fe}$ in the marine environment. But exceptions may well be possible, if local conditions including $\mathrm{Fe}_{\text {dis }}$ concentration, $\mathrm{pH}$, alkalinity, and the concentration of suspended $\mathrm{Mn}$ and $\mathrm{Fe}$ oxyhydroxides combine in a way that allows a shift of the overall reaction to a more equilibrium-type controlled isotope fractionation. Another hydrothermal plume study did observe a different development of isotope ratios during progressive oxidative $\mathrm{Fe}$ precipitation more in line with an equilibrium controlled isotope fractionation during oxidative precipitation (Severmann et al., 2004). 
To complete the discussion, potential reactions other than oxidative precipitation should be considered. These are, however, constrained by one fundamental observation. The overall isotope effect observable in the concentration profile is a transfer of isotopically light $\mathrm{Fe}$ from $\mathrm{Fe}_{\text {dis }}$ into $\mathrm{Fe}_{\mathrm{SPM}}$ across the ferruginous layer, which leads to a progressively smaller pool of $\mathrm{Fe}_{\mathrm{dis}}$ enriched in the heavy isotopes (Fig. 2d). A number of known reactions with reported Fe-isotope fractionation appear unlikely with respect to this observation. For instance, adsorption of $\mathrm{Fe}^{2+}$ onto preformed $\mathrm{Fe}_{\mathrm{IOH}}$ surfaces favors removal of heavy $\mathrm{Fe}$ isotopes from solution (Crosby et al., 2007; Mikutta et al., 2009) and cannot explain the observed $\Delta{ }^{56} \mathrm{Fe}_{\mathrm{IOH}-\mathrm{Fe}(\mathrm{II}) \mathrm{aq}}<0$. Another process, the coagulation of colloids and subsequent settling, is likely to occur in principle, but unlikely to affect the measured overall fractionation between dissolved $\mathrm{Fe}(<0.45 \mu \mathrm{m})$ and suspended matter $>0.45 \mu \mathrm{m}$ in a fundamental way, because such coagulation itself does not lead to significant Fe isotope fractionation (Escoube et al., 2009).

\subsection{Fe isotopes in the euxinic zone}

Discussion of the euxinic water column is limited to its upper, only mildly euxinic part (150-190 m depth). Here, the $\mathrm{Fe}_{\text {dis }}$ and $\mathrm{H}_{2} \mathrm{~S}$ concentration profile viewed in light of previously defined conditions of $\mathrm{FeS}$ precipitation in the EGB (Dyrssen and Kremling, 1990) suggests undersaturation with respect to solid Fe-sulfides in the EGB water column at the time of sampling. This is confirmed by a general absence of sulfide particles in detailed SEM/EDX scans of Fe (Dellwig et al., 2010). In addition, sulfides present at the surface sediments in the Gotland Basin have a much lower $\delta^{56} \mathrm{Fe}$ (around $-1.5 \%$, Fehr et al., 2010) than FesPM in the 2005 EGB water column ( -0.4 to $-0.1 \%$, Fig. $2 d)$. In order to explain the downward trends in $\mathrm{Fe}_{\mathrm{SPM}}$ concentration and $\delta^{56} \mathrm{Fe}_{\text {SPM }}$ in apparent absence of sulfidic particle formation, two variants of a reaction path dominated by microbial reduction and their likely $\mathrm{Fe}$ isotopic evolution will be discussed in the following.

In the sampled euxinic part of the EGB, negative $\delta^{56} \mathrm{Fe}$ values of $\mathrm{Fe}_{\text {dis }}$ prevail $\left(\delta^{56} \mathrm{Fe}_{\mathrm{dis}} \sim-0.4 \%\right.$, Fig. $\left.2 \mathrm{c}\right)$. $\mathrm{HCl}-$ leachable $\mathrm{Fe}$ in EGB sediments, a crude approximation of reactive $\mathrm{Fe}$ (Poulton and Canfield, 2005), ranges from $\delta^{56} \mathrm{Fe}=-0.27$ to +0.21 (Fehr et al., 2010). Euxinic EGB $\delta^{56} \mathrm{Fe}_{\text {dis }}$ values of $\sim-0.4 \%$ could therefore in principle be the result of early diagenetic dissimilatory reduction of $\mathrm{Fe}_{\mathrm{IOH}}$ in the sediments and subsequent efflux of low $\delta^{56} \mathrm{Fe}_{\text {dis }}$ into the water column. Euxinic water column $\mathrm{Fe}_{\text {dis }}$ concentration would then be controlled by diffusion from the bottom sediments. The shape of the $\mathrm{Fe}_{\text {dis }}$ concentration profile (Fig. 2d) may count in support of this path. However, the generally higher sulfide concentration in interstitial water compared to the overlying water column, and common amorphous FeS precipitation in the EGB sediments (Carman and Rahm, 1997), effectively limits such efflux from the eux- inic basin floor sediments. The presence of Fe-sulfides in the top layer of sediment in 2006 (Fehr et al., 2010) - recovered half a year after this study's cruise - suggests that pore water $\mathrm{Fe}_{\text {dis }}$ is removed by sulfide precipitation while excess dissolved sulfide from microbial sulfate reduction diffuses into the water column. Generally, Fe-flux from euxinic sediments underlying the ferruginous or euxinic water column is considered to be only a minor source of dissolved Fe in confined anoxic basins (Anderson and Raiswell, 2004).

An alternative explanation for the rising EGB euxinic $\mathrm{Fe}_{\mathrm{dis}}$ concentration with depth and the absolute $\delta^{56} \mathrm{Fe}_{\text {dis }}$ values is dissimilatory $\mathrm{Fe}$ reduction of suspended $\mathrm{Fe}_{\mathrm{IOH}}$ in the water column. The observed increase in $\delta^{56} \mathrm{Fe}$ SPM from -0.4 to $-0.1 \%$ o between euxinic depths of 150 and $170 \mathrm{~m}$ is similar to typical early diagenetic sedimentary reactive Fe profiles where iron-reducing microbes mobilize $\mathrm{Fe}$ and leave the residual $\mathrm{Fe}_{\mathrm{IOH}}$ increasingly enriched in heavy $\mathrm{Fe}$ isotopes with depth (Staubwasser et al., 2006). The value of $\delta^{56} \mathrm{Fe}_{\text {dis }}$ in the mildly euxinic EGB water column is comparable to $\delta^{56} \mathrm{Fe}_{\mathrm{SPM}}$ in the overlying ferruginous layer, which could result from a simple near-quantitative mass transfer of reactive $\mathrm{Fe}_{\mathrm{IOH}}$ into $\mathrm{Fe}_{\text {dis }}$ over the entire anoxic water column, i.e., a rather efficient redox cycle in the water column.

Reactive non-sulfide $\mathrm{Fe}$ leached from the EGB surface sediment layer $\left(\delta^{56} \mathrm{Fe}=-0.36 \%\right.$ ) is isotopically different from $\mathrm{Fe}_{\mathrm{SPM}}$ within the euxinic water column $\left(\delta^{56} \mathrm{Fe}_{\mathrm{SPM}}=-0.11 \%\right.$ at $170 \mathrm{~m}$ and $-0.09 \%$ at $\left.190 \mathrm{~m}\right)$. Because at the time of sampling, FesPM is dominantly made of non-sulfide reactive Fe (Dellwig et al., 2010). This would suggest that surface sediment reactive $\mathrm{Fe}$ and reactive $\mathrm{Fe}_{\text {SPM }}$ in the water column are from different sources. The one-time observation of $\mathrm{Fe}$ isotope distribution presented here could be the consequence of an operative Fe-shuttle of shelf-to-basin transport as suggested by Anderson and Raiswell (2004). This model emphasizes transport of suspended matter rather than solute transport as suggested by Severmann et al. (2006). Accordingly, the high concentration of reactive $\mathrm{Fe}$ in the pelagic sediments of anoxic marginal seas may mostly originate from "lithogenous-coupled" processes, i.e., particulate reactive $\mathrm{Fe}_{\mathrm{IOH}}$ originating from the shelf and deposited in association with silicate sediments. Near-bottom nepheloid flow in the EGB represents the largest lithogenous flux (Leipe et al., 2008). Such flow effectively bypasses the water column and thus could explain the observed isotopic difference between sediment reactive $\mathrm{Fe}$ and reactive FespM in the EGB.

The inventory of $\mathrm{Fe}_{\mathrm{dis}}$ and $\mathrm{Fe}_{\mathrm{SPM}}$ in the EGB water column is apparently maintained by reductive dissolution of reactive $\mathrm{Fe}_{\mathrm{IOH}}$ particles originating from two sources within the water column. The first is diagenetically recycled Fe from the shelf escaping nepheloid near-bottom flow, but precipitated later in the oxic water column. The second is $\mathrm{Fe}_{\mathrm{IOH}}$ from the internal redox cycle between the reducing and oxidizing layers in the EGB water column. The two constitute the "lithogenous-decoupled" flux (Anderson and Raiswell, 
2004). Apparently, this flux results in the buildup of $\mathrm{Fe}_{\mathrm{dis}}$ over the first few years after the last major deep water intrusion in 2003, as shown in the 2003-2008 time series data by Turnewitsch and Pohl (2010). The consequence of an increasing inventory of $\mathrm{Fe}_{\mathrm{dis}}$ is an increase in precipitation of $\mathrm{FeFe}_{\mathrm{IOH}}$ across the ferruginous-oxic interface and an increase in FesPM inventory (Turnewitsch and Pohl, 2010). According to $\mathrm{Fe}$ isotope ratios observed in $\mathrm{Fe}_{\text {dis }}$ and $\mathrm{Fe}_{\mathrm{SPM}}$ in the EGB, such buildup should concentrate light Fe isotopes inside the redox cycle. This continues until equilibrium concentrations for Fe-sulfides are reached and removal by $\mathrm{Fe}$ sulfide precipitation commences. A steady state between $\mathrm{Fe}$ added to the anoxic water column by reductive dissolution of "lithogenous-decoupled flux" and particulate Fe settling out of the water column ensues.

\subsection{Fe isotopes in oxic water layer}

Fe isotope fractionation in the surface layer cannot be discussed in a representative fashion for lack of sampling detail. The uppermost two samples of $\delta^{56} \mathrm{Fe}_{\mathrm{SPM}}(-0.1$ to $-0.2 \%$ ) in this study from the EGB compare well with the range of -0.05 to $-0.3 \%$ measured in near-surface particulate $\mathrm{Fe}$ above Landsort Deep (Gelting et al., 2010), another basin in the central Baltic proper.

The oxygenated base of the EGB pycnocline ( 80 and $120 \mathrm{~m}$ ) shows high $\delta^{56} \mathrm{Fe}_{\text {dis }}$ similar to values in the surface mixed layer. These are not explainable with low $\delta^{56} \mathrm{Fe}_{\text {dis }}$ efflux described from ferruginous sediments present along the basin margins as observed in a similar environment elsewhere (Severmann et al., 2010) and inferred from surface sediment measurements from the EGB (Fehr et al., 2010). This may suggest that any low $\delta^{56} \mathrm{Fe}$ efflux is rapidly transferred into a particulate phase by oxidative precipitation with the kinetic fractionation described above. Alternative explanations, which remain to be verified by pore water measurements, are that the efflux from ferruginous EGB sediments is not significant, or the efflux does not have a low $\delta^{56} \mathrm{Fe}$. The isotopic composition of $\mathrm{Fe}_{\text {dis }}$ in the upper water column of the EGB may in principle be explained by deep overturning in winter and mixing of high $\delta^{56} \mathrm{Fe}_{\text {dis }}$ from soluble $\mathrm{Fe}$ just above the ferruginous layer, but see Breitbarth et al. (2009) for a different conclusion. Authigenic Mn-oxide formation some $20 \mathrm{~m}$ above the ferruginous layer and redox exchange of Fe at Mn-oxide particle surfaces (Dellwig et al., 2010) may impact the $\mathrm{Fe}_{\mathrm{dis}}$ concentration and isotopic composition of the oxic water column.

At the month of sampling (October 2005), suspended matter is generally still largely dominated by sinking organic debris (Pohl et al., 2004). Since the Baltic Sea is a large estuary - surface salinity of the EGB being in the 3\%o range a significant influence by runoff for both $\mathrm{Fe}_{\text {dis }}$ and $\mathrm{Fe}_{S P M}$ is highly likely. For Fe $\mathrm{SPM}_{\mathrm{SPM}}$ this influence is well described during winter (Pohl et al., 2004). The size of this contribution to $\mathrm{Fe}_{\text {dis }}$ cannot currently be addressed from an isotopic per- spective for lack of data, but as $\mathrm{Fe}_{\text {dis }}$ concentrations are low in the oxic water column, dissolution of fluvial lithogenous particles may well be a significant source of $\mathrm{Fe}_{\mathrm{dis}}$ and consequently also determine $\delta^{56} \mathrm{Fe}_{\text {dis }}$. Because at depths below $50 \mathrm{~m} \mathrm{Fe}_{\text {dis }}$ and $\mathrm{Fe}_{\mathrm{SPM}}$ differ isotopically, and $\delta^{56} \mathrm{Fe}_{\mathrm{dis}}$ is comparable to the top of the redox-cline, at least some contribution to $\mathrm{Fe}_{\text {dis }}$ by efflux from the redox-cline below is likely.

Another potential source of $\mathrm{Fe}$ is atmospheric deposition, but because fluxes below the thermocline are dominated by lateral transport (Pohl et al., 2006), any potential contribution will be difficult to deduct from water column measurements. The atmospheric contribution for trace metal pollutants $(\mathrm{Cu}$ and $\mathrm{Zn})$ has been estimated at a few percent of water column flux for the EGB. Because the enrichment factor against the Earth's crustal average for Fe SPM $_{\text {is con- }}$ siderably lower than for these trace elements, it is unlikely that anthropogenic emissions contribute significantly to the total external $\mathrm{Fe}_{\mathrm{SPM}}$ flux, unless that flux consists mainly of lithogenous Fe. Lithogenous river discharge remains the most plausible external source of $\mathrm{Fe}$ at this point.

\section{Conclusions}

Kinetic isotope fractionation dominates oxidative precipitation of $\mathrm{Fe}$ at the oxic-anoxic interface in the EGB and partitions light $\mathrm{Fe}$ isotopes preferentially into suspended $\mathrm{Fe}$. The overall $\mathrm{Fe}$ isotope fractionation factor may change with reaction rates and in response to different reaction paths with different rate constants. The controls of reaction rates and rate constants have been described in detail in previous studies (King, 1998; Rose and Waite, 2002; Santana-Casiano et al., 2006; Pham and Waite, 2008). The discussion of Fe isotope fractionation has been presented here following Anbar (2004) with an emphasis on the effects of abundant suspended particulate $\mathrm{Mn}$ and $\mathrm{Fe}$ oxyhydroxides, and fastreacting dissolved $\mathrm{Fe}$ species abundant at typical marine $\mathrm{pH}$. However, alternative kinetic fractionation paths (John et al., 2012) are possible in principle.

There is no low $\delta^{56} \mathrm{Fe}$ efflux from redox processes within the EGB detectable in the isotope data of the EGB water column. In fact, $\delta^{56} \mathrm{Fe}$ in dissolved $\mathrm{Fe}$ immediately above the water column redox boundary is the isotopically heaviest in the basin as a result of fractionation during oxidative precipitation. Anoxic marine basins may therefore not generally export low $\delta^{56} \mathrm{Fe}$ from diagenetic redox cycling in dissolved form into the open ocean.

The water column isotope data presented here are not easily reconciled with sedimentary data and tentatively suggest that reactive particulate $\mathrm{Fe}$ transport from the oxic shelf to the basin floor is bypassing the water column redox cycle and probably taking place as near-bottom nepheloid flow. Such flow is an important contributor to total sediment flux in the EGB (Leipe et al., 2008). The "benthic Fe shuttle" in marine anoxic basins - extended to covering Fe isotopes 
in sediments by Severmann et al. (2008) - may therefore be dominated by reactive $\mathrm{Fe}$ (and $\mathrm{Fe}$ isotopes accordingly) coupled to lithogenous flux as suggested by Anderson and Raiswell (2004) rather than involving open water column $\mathrm{Fe}_{\text {dis }}$ and $\mathrm{Fe}_{\mathrm{SPM}}$. The water column Fe isotope data of the EGB are consistent with largely "lithogenous-decoupled" processes, i.e oxidative precipitation and reductive dissolution occurring in the water column.

Outgoing fluxes of $\mathrm{Fe}$ from the Eastern Gotland Basin anoxic water column, i.e., residual dissolved $\mathrm{Fe}$ above the redox-cline and suspended-matter Fe eventually settling onto the seafloor, are both enriched in heavy $\mathrm{Fe}$ isotopes relative to ingoing fluxes of $\mathrm{Fe}_{\text {SPM }}$. Consequently, internal $\mathrm{Fe}$ redox cycling in an anoxic marine basin retains light isotopes within the anoxic water column during buildup of the basin's Fe inventory. Ranging from $\delta^{56} \mathrm{Fe}=-0.6$ to $+0.4 \%$, the Gotland Basin profile on average is only slightly below the average crustal value $\delta^{56} \mathrm{Fe} \sim 0.1 \%$ (Beard and Johnson, 2004, relative to the IRMM-14 standard). This suggests that the basin's Fe isotopic inventory is largely dominated by reactive Fe supply from adjacent lands, which nevertheless is intensely recycled across the basin's redox boundaries. In general, intense redox recycling and a high proportion of water column recycled reactive Fe oxyhydroxides within the total reactive Fe deposited onto the seafloor may therefore draw an anoxic basin's overall isotopic composition towards low $\delta^{56} \mathrm{Fe}$ values. The Fe isotope composition of an anoxic basin's water column and of its authigenic minerals should reflect the proportion of $\mathrm{Fe}$ recycled within the basin versus $\mathrm{Fe}$ supplied from external sources. A large inventory of $\mathrm{Fe}$ in the water column combined with intense redox recycling and relatively low lithogenous input of reactive $\mathrm{Fe}$ from continental oxidative weathering may principally lead to very low $\delta^{56} \mathrm{Fe}$ values of the basin's reactive Fe inventory. Such a scenario would be conceivable on a large scale during times of low atmospheric oxygen and high seawater concentration of dissolved Fe in the early and mid-Proterozoic and may provide an explanation for generally low $\delta^{56} \mathrm{Fe}$ values found in some pyritic shale deposited prior to $2.3 \mathrm{Ga}$ years ago.

Acknowledgements. The authors thank the masters and crews of the FS Alkor and Professor A. Penck for their professional assistance during the two cruises that contributed to the presented results. This study was supported by a DFG grant to MS and FvB. MS, RS, FvB and SK would like to honor our co-author Christa Pohl, who passed away shortly after this manuscript was submitted.

Edited by: C. P. Slomp

\section{References}

Anbar, A. D.: Iron stable isotopes: beyond biosignatures, Earth Planet. Sc. Lett., 217, 223-236, 2004.

Anbar, A. D. and Rouxel, O.: Metal Stable Isotopes in Paleoceanography, Annu. Rev. Earth Planet. Sci., 3, 717-46, 2007.

Anderson, T. F. and Raiswell, R.: Sources and Mechanisms for the enrichment of highly reactive $\mathrm{Fe}$ in euxinic sediments of the Black Sea sediments, Am. J. Sci., 304, 203-233, 2004.

Bennett, S. A., Rouxel, O., Schmidt, K., Garbe-Schönberg, D., Statham, P. J., and German, C. R.: Iron Isotope fractionation in a buoyant hydrothermal plume, $5^{\circ} \mathrm{S}$ Mid-Atlantic Ridge, Geochim. Cosmochim. Ac., 73, 5619-5634, 2009.

Beard, B. L. and Johnson, C. M.: Fe Isotope Variations in the Modern and Ancient Earth and Other Planetary Bodies, Rev. Min. Geochem., 55, 319-357, 2004.

Breitbarth, E., Gelting, J., Walve, J., Hoffmann, L. J., Turner, D. R., Hassellöv, M., and Ingri, J.: Dissolved iron (II) in the Baltic Sea surface water and implications for cyanobacterial bloom development, Biogeosciences, 6, 2397-2420, doi:10.5194/bg-6-23972009, 2009.

Bullen, T. D., White, A. F., Childs, C. W., Vivit, D. V., and Schulz, M. S.: Demonstration of significant abiotic iron isotope fractionation in nature, Geology, 29, 699-702, 2001.

Busign, V., Jezequel, D., Louvat, P., Viollier, E., and Michard, G.: Iron Isotopes in Lake Pavin (French Massif Central): A Window to the Precambrian Ocean, Eos. Trans. AGU, 89, Fall Meet. Suppl., Abstract PP31C-1510, 2008.

Butler, I. B., Archer, C., Vance, D., Oldroyd, A., and Rickard, D.: $\mathrm{Fe}$ isotope fractionation on $\mathrm{FeS}$ formation in ambient aqueous solution, Earth Planet. Sc. Lett., 236, 430-442, 2005.

Canfield, D. E. and Thamdrup, B.: Towards a consistent classification scheme for geochemical environments, or, why we wish the term "suboxic" would go away, Geobiology, 7, 385-392, 2009.

Carman, R. and Rahm, L.: Early diagenesis and chemical characteristics of interstitial water and sediments in the deep deposition bottoms of the Baltic proper, J. Sea Res., 37, 25-47, 1997.

Croal, L. R., Johnson, C. M., Beard, B. L., and Newman D. K.: Iron isotope fractionation by $\mathrm{Fe}(\mathrm{II})$-oxidizing photoautotrophic bacteria, Geochim. Cosmochim. Ac., 68, 1227-1242, 2004.

Crosby, H. A., Roden, E. E., Johnson, C. M., and Beard, B. L.: The mechanisms of iron isotope fractionation produced during dissimilatory $\mathrm{Fe}(\mathrm{III})$ reduction by Shewanella putrefaciens and Geobacter sulfurreducens, Geobiology, 5, 169-189, 2007.

Dellwig, O., Leipe, T., März, Ch., Glockzin, M., Pollehne, F., Schnettker, B., Yakushev, E. V., Böttcher, M. E, and Brumsack, H.-J.: A new particulate Mn-Fe-P shuttle at the redoxcline of anoxic basins, Geochim. Cosmochim. Ac., 74, 7100-7115, 2010.

Dideriksen, K., Baker, S. A., and Stipp, S. L. S.: Equilibrium Fe isotope fractionation between inorganic aqueous $\mathrm{Fe}(\mathrm{III})$ and the siderophore complex, Fe(III)-desferrioxamine B, Earth Planet. Sc. Lett., 269, 280-290, 2008.

Dyrssen, D. and Kremling, K.: Increasing hydrogen sulfide concentration and trace metal behavior in the anoxic Baltic waters, Mar. Chem., 30, 193-204, 1990.

Escoube, R., Rouxel, O. J., Sholkovitz, E., and Donard, O. F. X.: Iron isotope systematics in estuaries: The case of North River, Massachusetts (USA), Geochim. Cosmochim. Ac., 73, 40454059, 2009. 
Fehr, M. A., Andersson, P. S., Halenius, U., Gustafsson, Ö., and Mörth, C. M.: Iron enrichments and Fe isotopic compositions of surface sediments from the Gotland Deep, Baltic Sea, Chem. Geol., 227, 310-322, 2010.

Gelting, J., Breitbarth, E., Stolpe, B., Hassellöv, M., and Ingri, J.: Fractionation of iron species and iron isotopes in the Baltic Sea euphotic zone, Biogeosciences, 7, 2489-2508, doi:10.5194/bg7-2489-2010, 2010.

Grasshoff, K., Ehrhardt, M., Kremling, K., and Anderson, L. G.: Methods of seawater analysis, Wiley-VCH, Hoboken, 1983.

Hille, S., Leipe, T., and Seifert, T.: Spatial variability of recent sedimentation rates in the Eastern Gotland Basin (Baltic Sea), Oceanologia, 48, 297-317, 2006.

Jenkyns, H. C., Matthews, A., Tsikos, H., and Erel, Y.: Nitrate reduction, sulfate reduction, and sedimentary iron isotope evolution during the Cenomanian-Turonian oceanic anoxic event, Paleoceanography, 22, PA3208, doi:10.1029/2006PA001355, 2007.

John, S. G. and Atkins, J. F.: Analysis of dissolved iron isotopes in seawater, Mar. Chem., 119, 65-76, 2010.

John, S. G., Mendez, J., Moffett, J., and Atkins, J. F.: The flux of iron and iron isotopes from San Pedro Basin sediments, Geochim. Cosmochim. Ac., 93, 14-29, 2012.

Johnson, C. M., Beard, B. L., and Roden, E. E.: The iron isotope fingerprints of redox and biogeochemical cycling in the modern and ancient Earth, Earth Planet. Sc. Lett., 36, 457-493, 2008.

Karlson, B., Axe, P., Funkquist, L., Kaitala, S., and Sørensen, K.: Infrastructure for marine monitoring and operational oceanography, Reports Oceanography, Swedish Meteorological and Hydrological Institute, 39, pp. 101, 2009.

King, D. W.: Role of carbonate speciation on the oxidation rate of $\mathrm{Fe}(\mathrm{II})$ in aquatic systems, Environ. Sci. Technol., 32, 2997-3003, 1998.

Krauskopf, K. B and Bird, D. K.: Introduction to Geochemistry, McGraw-Hill, New York, USA, 1995.

Lacan, F., Radic, A., Jeandel, C., Poitrasson, F., Sarthou, G., Pradoux, C., and Freydier, R.: Measurement of the isotopic composition of dissolved iron in the open ocean, Geophys. Res. Lett., 35, GL24610, doi:10.1029/2008GL035841, 2008.

Landing, W. M. and Westerlund, S.: The solution chemistry of iron(II) in Framvaren Fjord, Mar. Chem., 23, 329-343, 1988.

Leipe, T., Harff, J., Meyer, M., Hille, S., Pollehne, F., Schneider, R., Kowalski, N., and Brügmann, L.: Sedimentary records of environmental changes and anthropogenic impacts during the past decades, in: State and evolution of the Baltic Sea, 1952-2005, edited by: Feistel. R., Nausch, G., and Wasmund, N., Wiley, Hoboken, USA, 395-439, 2008.

Lewis, B. L. and Landing, W. M.: The biogeochemistry of Manganese and Iron in the Black Sea, Deep-Sea Res., 38, 773-803, 1991.

Matthäus, W., Nehring, D., Feistel, R., Nausch, G., Mohrholz, V., and Lass, H.-U.: The inflow of highly saline water into the Baltic Sea, in: State and evolution of the Baltic Sea, 1952-2005, edited by: Feistel, R., Nausch, G.,and Wasmund, N., Wiley, Hoboken, USA, 265-309, 2008.

Meier, H. E. M., Feistel, R., Piechura, J., Arneborg, L., Burchard, H., Fiekas, V., Golenko, N., Kuzmina, N., Mohrholz, V., Nohr, C., Paka, V. T., Sellschopp, J., Stips, A., and Zhurbas V.: Ventilation of the Baltic Sea deep water: a brief review of present knowledge from observation and models, Oceanologia, 48, 133-
164, 2006.

Mikutta, C., Wiederhold, J. G., Cirpka, O. A., Hofstetter, T. B., Bourdon, B., and von Gunten, U.: Iron isotope fractionation and atom exchange during sorption of ferrous iron to mineral surfaces, Geochim. Cosmochim. Ac., 73, 1795-1812, 2009.

Miller, J. N. and Miller, J. C.: Statistics and chemometrics for analytical chemistry, Pearson, Harlow, 2005.

Millero, F. J.: Chemical Oceanography, CRC Press, Boca Raton, 2006.

Murray, J. W. and Yakushev, E.: The suboxic transition zone in the Black Sea, in: Past and present water column anoxia, edited by: Neretin, L. N., Springer, Dordrecht, The Netherlands, 105-137, 2006.

Nausch, G., Nehring, D., and Nagel, K.: Nutrient Concentration, trends and their relation to eutrophication, in: State and evolution of the Baltic Sea, 1952-2005, edited by: Feistel, R., Nausch, G. and Wasmund, N., Wiley, Hoboken, USA, 337-366, 2008.

Neretin, L. N., Pohl, C., Jost, G., Leipe, T., and Pollehne, F.: Manganese cycling in the Gotland Deep, Baltic Sea, Mar. Chem., 82 125-143, 2003.

Pham, A. N. and Waite, T. D.: Oxygenation of Fe(II) in natural waters revisited: Kinetic modeling approaches, rate constant estimation and the importance of various reaction pathways, Geochim. Cosmochim. Ac., 72, 3616-3630, 2008.

Pohl, C. and Hennings, U.: The coupling of long-term trace metal trends to internal trace metal fluxes at the oxic-anoxic interface in the Gotland Basin $\left(57^{\circ} 19.20^{\prime} \mathrm{N} ; 20^{\circ} 03.00^{\prime} \mathrm{E}\right)$ Baltic Sea, J. Mar. Sys., 56, 207-225, 2005.

Pohl, C. and Hennings, U.: Trace metals in Baltic seawater. In State and evolution of the Baltic Sea, 1952-2005, edited by: Feistel, R., Nausch, G., and Wasmund, N., Wiley, Hoboken, USA, 367393, 2008.

Pohl, C., Löffler, A., and Hennings, U.: A sediment trap flux-study for trace metals under seasonal aspects in the stratified Baltic Sea (Gotland Basin; $57^{\circ} 19.20^{\prime}$ N; $20^{\circ} 03.00^{\prime}$ E), Mar. Chem., 84, 143-160, 2004.

Pohl, C., Löffler, A., Schmidt, M., and Seiffert, T.: A trace metal $(\mathrm{Pb}, \mathrm{Cd}, \mathrm{Zn}, \mathrm{Cu})$ balance for surface waters in the eastern Gotland Basin, Baltic Sea, J. Mar. Sys., 60, 381-395, 2006.

Poulton, S. W. and Canfield, D. E.: Development of a sequential extraction procedure for iron: implications for iron partitioning in continentally derived particulates, Chem. Geol., 214, 209-221, 2005.

Radic, A., Lacan, F., and Murray, J. W.: Iron isotopes in the seawater of the equatorial Pacific Ocean: New constraints for the oceanic iron cycle, Earth Planet. Sc. Lett., 306, 1-10, 2011.

Rose, A. L. and Waite, T. D.: Kinetic model for Fe(II) oxidation in seawater in the absence and presence of natural organic matter, Environ. Sci Technol., 36, 433-444, 2002.

Rouxel, O. J., Bekker, A., and Edwards, K. J.: Iron isotope constraints on the Archean and Paleoproterozoic ocean redox state, Science, 307, 1088-1091, 2005.

Rouxel, O., Sholkovitz, E, Charette, M., and Edwards, J. K.: Iron isotope fractionation in subterranean estuaries, Geochim. Cosmochim. Ac., 72, 3413-3430, 2008.

Santana-Casiano, J. M., Gonzales-Davila, M., and Millero, F. J.: The role of $\mathrm{Fe}$ (II) species in the oxidation of $\mathrm{Fe}(\mathrm{II})$ in natural waters in the presence of $\mathrm{O}_{2}^{-}$and $\mathrm{H}_{2} \mathrm{O}_{2}$, Mar. Chem., 99, 70-82, 2006. 
Schoenberg, R. and von Blanckenburg, F.: An assessment of the accuracy of stable $\mathrm{Fe}$ isotope ratio measurements on samples with organic and inorganic matrices by high-resolution multicollector ICP-MS, Int. J. Mass Spec., 242, 257-272, 2005.

Schoenberg, R., Zink, S.,Staubwasser, M., and von Blanckenburg, F.: The stable $\mathrm{Cr}$ isotope inventory of solid Earth reservoirs determined by double spike MC-ICP-MS, Chem. Geol., 249, 294306, 2008.

Severmann, S., Johnson, C. M., Beard, B. L., German, C. R., Edmonds, H. N., Chiba, H., and Green, D. R. H.: The effect of plume processes on the $\mathrm{Fe}$ isotope composition of hydrothermally derived $\mathrm{Fe}$ in the deep ocean as inferred from the Rainbow vent-site, Mid-Atlantic Ridge, $36^{\circ} 14^{\prime} \mathrm{N}$, Earth Planet. Sc. Lett., 225, 63-76. 2004.

Severmann, S., Johnson, C.M., Beard, B. L., and McManus, J.: The effect of early diagenesis on the Fe isotope compositions of porewaters and authigenic minerals in continental margin sediments, Geochim. Cosmochim. Ac., 70, 2006-2022, 2006.

Severmann, S., Lyons, T. W., Anbar, A., McManus, J., and Gordon, G.: Modern iron isotope perspective on the benthic iron shuttle and the redox evolution of ancient oceans, Geology, 36, 487-490, 2008.

Severmann, S., McManus, J., Berelson, W. M., and Hammond, D. E.: The continental shelf benthic iron flux and its isotope composition, Geochim. Cosmochim. Ac., 74, 3984-4004, 2010.

Skulan, J. L., Beard, B. L., and Johnson, C. M.: Kinetic and equilibrium $\mathrm{Fe}$ isotope fractionation between aqueous $\mathrm{Fe}(\mathrm{III})$ and hematite, Geochim. Cosmochim. Ac., 66, 2995-3015, 2006.
Staubwasser, M., von Blanckenburg, F., and Schoenberg, R.: Iron isotopes in the early marine diagenetic iron cycle, Geology, 34, 629-632, 2006.

Strady, E., Pohl, C., Yakushev, E. V., Krüger, S., and Hennings, U.: PUMP-CTD-System for trace metal sampling with a high vertical resolution, a test in the Gotland Basin, Baltic Sea, Chemosphere, 70, 1309-1319, 2008.

Teutsch, N., Schmid, M., Müller, B., Halliday, A. N., Bürgmann, H., and Wehrli, B.: Large iron isotope fractionation at the oxicanoxic boundary in Lake Nyos, Earth Planet. Sc. Lett., 285, 5260, 2009.

Turnewitsch, R. and Pohl, C.: An estimate of the efficiency of the iron- and manganese-driven dissolved inorganic phosphorus trap at an oxic/euxinic water column redoxcline, Global Biogeochem. Cy., 24, GB4025, doi:10.1029/2010GB003820, 2010.

von Blanckenburg, F., Mamberti, M., Schoenberg, R., Kamber, B., and Webb, G. E:. The iron isotope composition of microbial carbonate, Chem. Geol., 249, 113-128, 2008.

Welch, S. A., Beard, B. L., Johnson, C. M., and Bratemann, P. S.: Kinetic and equilibrium $\mathrm{Fe}$ isotope fractionation between aqueous Fe(II) and Fe(III), Geochim. Cosmochim. Ac., 67, 42314250, 2003.

Wijsman J. W. M., Middelburg J. J., and Heip, C. H. R.: Reactive iron in Black Sea Sediments: implications for iron cycling, Mar. Geol. 172, 167-180, 2001.

$\mathrm{Wu}, \mathrm{J} .:$ Determination of picomolar iron in seawater by double $\mathrm{Mg}(\mathrm{OH}) 2$ precipitation isotope dilution high-resolution ICPMS, Mar. Chem, 103, 370-381, 2007. 